\title{
The Phytochemical constituents and the effects of methanol extracts of Phyllanthus amarus leaves (kidney stone plant) on the hormonal parameters of Male guinea pigs. \\ ${ }^{1}$ OBIANIME A.W; ${ }^{2}$ UCHE, F.I.
}

\author{
${ }^{I}$ Department of Pharmacology University of Port Harcourt \\ ${ }^{2}$ Department of Pharmacognosy and Ethnotherapy University of Port Harcourt, Nigeria. \\ Email: uchefideliaijeoma@yahoo.com.08037066891
}

\begin{abstract}
The effects of the methanolic extracts of the leaves of Phyllanthus amarus on the hormonal parameters of male Guinea pigs were investigated. The phytochemical screening of the leaves of Phyllanthus amarus was also carried out. The hormonal parameters investigated are testosterone, Leutinizing and Follicle stimulating hormone. The methanolic extract of the Phyllanthus amarus leaves $(50-800 \mathrm{mg} / \mathrm{kg})$ caused a statistically significance increase ( $\mathrm{P}<0.001$, ANOVA) in the level of Testosterone of the male Guinea pigs, from $2.3 \pm 0.06$ to $3.9 \pm 0.05,4.3$ \pm 0.6 and $2.8 \pm 0.6$ after the $7,14^{\text {th }}$ and $21^{\text {st }}$ day of the administration of the extracts respectively. The highest increase was obtained after $14^{\text {th }}$ day of treatment $(4.3 \pm .05)$. These effects were very comparable to the effects of Vitamin E on the testosterone of male Guinea pigs, which were obtained to be $3.0 \pm 0.01,3.1 \pm 0.16$ and $2.4 \pm 0.30$ for $7,14^{\text {th }}$ and $21^{\text {st }}$ day respectively. These effects were dose- and time- dependents. The optimum effects $(4.3 \pm .05)$ were obtained at $400 \mathrm{mg} / \mathrm{kg}$ of Phyllanthus amarus.

Furthermore, the methanol extracts of Phyllanthus amarus $(800 \mathrm{mg} / \mathrm{kg}$ ) caused an insignificant change in the levels of Leutenizing (LH) and Follicle stimulating (FSH) hormones from 3.1 \pm 0.22 and $1.6 \pm 0.50$ to $3.0 \pm 0.08$ and $1.5 \pm 0.13$ respectively. These effects were also comparable to the effects of Vitamin E on these hormones.

Finally, the phytochemical screening of the leaves of Phyllanthus amarus revealed the presence of flavonoids, tannins, alkaloids, terpenoids, steroids, saponins and cardiac glycosides. This may support or justify the claims on the use of the aerial part of this plant by traditional medicine practitioners to increase/improve libido and reproductive function in men. Although further studies need to be done to investigate the contribution of the seeds of this plant in the improvement of libido in men; also to isolate and characterize the active principles in the leaf extracts. @ JASEM
\end{abstract}

Phyllanthus amarus Schum (Family Euphorbiaceae) is a widely distributed small erect, tropical annual herbal shrub whose stem has green capsule, and grows up to $10-50 \mathrm{~cm}$ high and blooms with flowers with 5 white sepals and apical acute anther. The fruit has green capsules, and smooth and fruiting pedicels. The seeds are longitudinally rugose. It is locally called Iyin-olobe (Yoruba, south- west Nigeria) (Adeneye et al, 2006) or kidney stone plant. In Traditional medicine, it is used for its hepatoprotective , antidiabetic, antihypertensive, analgesic, anti-inflammatory and antimicrobial properties (Adeneye et al., 2006). The plant is also used in the treatment of stomach disorders, skin diseases and cold (Kokwaro, 1976, Iwu,1993). It has antidiarrheal effect (Odetola and Akojenu 2000). Its anti- viral activity against hepatitis B virus has been established (Thyagarajan et al., 1988; Meixa et al 1995); anticarcinogenic(Joy and kutten, 2000) and antimutagenic activities (Joy and Kutten, 1998). It also has anti- nociceptive and anti- inflammatory activities (kassuya et al, 2003), antidiabetic and antilipidemic potentials (Adeneye et al 2006).

So far, there is no report on the effects of Phyllanthus amarus on hormomal parameters, such as Testosterone, Follicle stimulating and Leutenizing hormones.

Also there is claim on the use of aerial part of Phyllanthus amarus to improve libido or fertility in men, by traditional medicine practitioners. Based on this claim, this study came up to establish a scientific information on the effectiveness of Phyllanthus amarus as fertility agent by its effects on the hormonal parameters of male guinea pigs. And also to establish the contribution of the leaves of Phyllanthus amarus to this effect.

\section{MATERIALS AND METHODS}

All the chemicals used were of analar grade.

\section{Plant Material}

The leaves of Phyllanthus amarus were collected from the local garden within the premises of University of Port Harcourt in June 2008. The plant was identified and authenticated by Edwin Nwosu of department of Botany herbarium, University of Port Hacourt .Voucher specimen was maintained at the Herbarium.

The fresh leaves collected were air- dried for 10days, until a constant weight was attained.

\section{Preparation of Extract}

The dried leaves of Phyllanthus amarus were pulverized $(100 \mathrm{~g})$. The crude drug was extracted with methanol using Soxhlet extraction method. The solid residue obtained was kept in a capped container in a refrigerator. Different concentrations of the extract were reconstituted from this stock.

\section{Experimental animals}

The male guinea pigs were collected from the animal house of University of Port Harcourt. The weight of the animals ranges from $300-600 \mathrm{~g}$. The animals were 
allowed to acclimatize with the new environment for seven days before the experiment. They were housed in a cage of five animals per cage and were adequately feed throughout the experiment.

\section{Phytochemical screening}

Chemical tests were carried out on the methanolic extracts and on the powdered specimens using standard procedures to identify the constituents (Trease and Evans, 1989; Harborne, 1973) by characteristic colour changes as described by Sofowara, (1993); Odebedy and Sofowara, (1978).

\section{Hormonal assay}

The animals were grouped into 10 groups of five animals per group.

The animals from different groups were given diethyl ether anesthesia and dissected. Their respective blood samples were collected in lithium heparinized tubes.

\section{Leutanizing hormone (LH) and Follicle stimulating hormone (FSH) assay}

In the assay of LH and FSH, 50ml of standard or test sample was measured into appropriate well. $100 \mathrm{ml}$ of enzyme conjugate reagent was added into the well. This was gently mixed for 10 seconds and incubated at room temperature for 45 minutes. The incubated mixture was removed by flicking the plate contents into the well and washed 5 times with water. $100 \mathrm{ml}$ of tetra methyl was added to the incubated mixture at room temperature and allowed to react for 20minutes. The reaction was stopped by addition of $100 \mathrm{ml}$ of stop solution to the well and readings were taken at $450 \mathrm{~nm}$ within 15 minutes.

Concentration of the test (A) was calculated as follows:

$\mathrm{A}=[$ Absorbance of test/]X[Concentration of standard] Absorbance of standard

\section{Testosterone Enzyme immuno assay}

This was carried out in three stages namely:

Reaction of antibody with serum testosterone and testosterone label,

Magnetic solid phase separation step and Colour development step.

In the reaction of antiserum with serum testosterone and testosterone label, 50ul of test blood sample was pip petted into different tubes. The testosterone blocking reagent, diluted testosterone label and testosterone antiserum $(100 \mathrm{ul})$ were added to the test tube, covered and vortex mixed.

\section{Magnetic separation reagent; reaction}

$100 \mathrm{ul}$ of testosterone separation reagent was added to different test tubes, covered and vortex mixed. The tubes were incubated in water bath at $37^{\circ} \mathrm{C}$ for 30minutes.

The assay tubes were removed from water bath and placed on a magnetic base. The rack of tubes was kept upright in magnetic separation for 5 minutes after which the supernatant liquid from all the tubes were decanted. Then the tubes were changed from upright position and remove from the magnetic base.

\section{Washing step}

50ul of dilute testosterone enzyme immune assay (EIA) wash buffer was added to different tubes and vortex mixed. The rack of tubes was placed on a magnetic base. The tubes were kept upright in the magnetic separation for 5 minutes. The supernatant liquid were decanted from all the tubes and the separator was returned to an upright position The rack of tubes was removed from the magnetic base. The whole process was repeated. This process is essential to remove all unbound components.

\section{Colour development step}

500 ul of substrate solution was added to different test tubes, covered and votex mixed. The tubes were transferred to $37^{\circ} \mathrm{C}$ water bath and incubated for 6 minutes. The tubes were removed from the bath and $1 \mathrm{ml}$ of EIA stop buffer was added to the different tubes and mixed. The rack of tubes was placed onto a magnetic base and the tubes were kept upright in magnetic separation for 10 minutes. The absorbance of the test sample and standard were recorded spectrophotometrically and compared with the blank.

\section{Statistical analysis}

Data were expressed as mean \pm standard error of mean (S.E.M) .Results were subjected to statistical analysis using one way analysis of variance (ANOVA). $\mathrm{P}<0.05$ was accepted as significance. 


\section{RESULTS AND DISCUSSION}

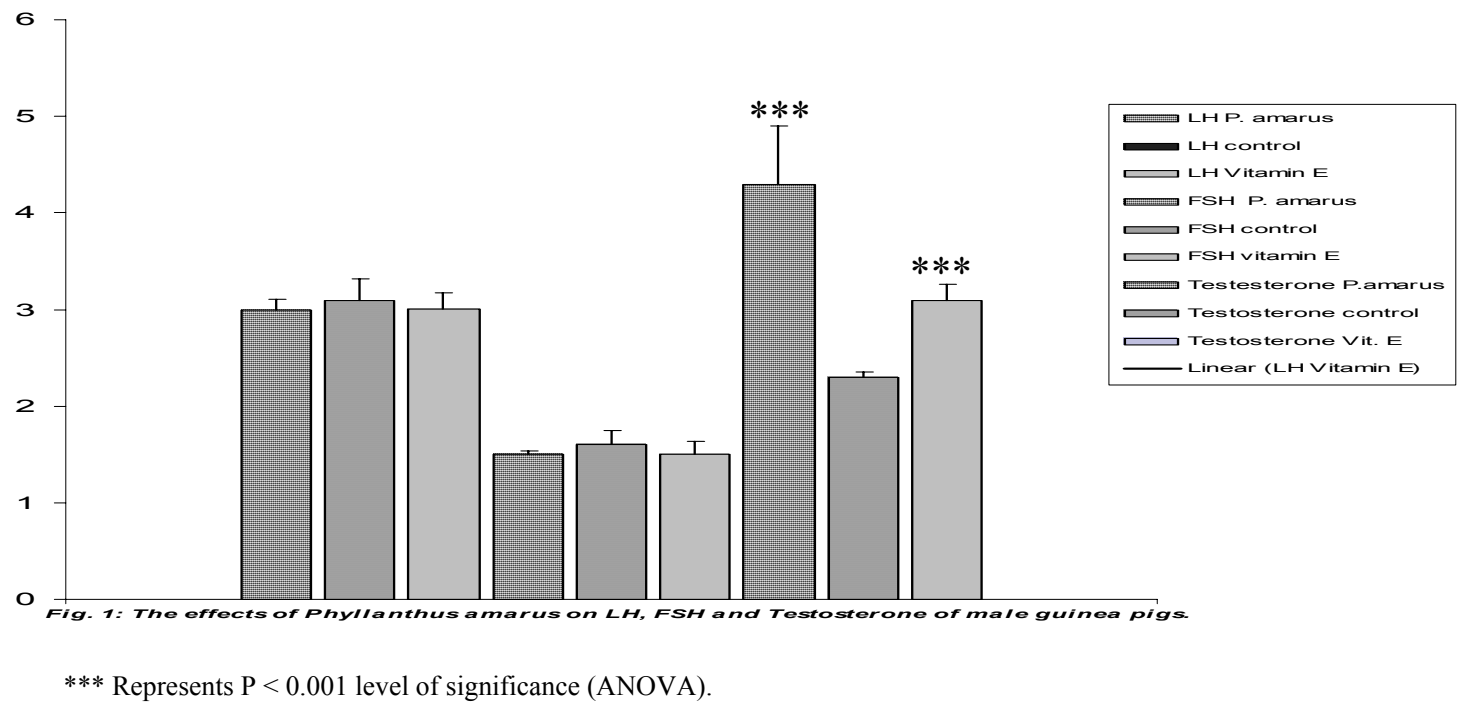

LHP represenst Leutenizing hormone level on treatment with P. amarus;

LHC Leutenizing hormone level, control;LHE Leutenizing hormone level on treatment with Vitamin E;FSHP Follicle stimulating hormone on treatment with P. amarus; FSHC Follicle stimulating hormone, control;FSHE Follicle stimulating hormone on treatment with Vitamin E;TP Testosterone level on treatment with P. amarus; TC Testosterone level, control; TE Testosterone level on treatment with Vitamin E.

Table 1: The dose -dependent effects of methanolic extracts of the leaf of Phyllanthus amarus on the hormonal parameters of male guinea pigs.

\begin{tabular}{llll}
\hline $\begin{array}{l}\text { Treatment } \\
(\mathrm{mg} / \mathrm{kg})\end{array}$ & $\begin{array}{l}\text { Leutenizing } \\
\text { Hormone }(\mathrm{mlu} / \mathrm{L})\end{array}$ & $\begin{array}{l}\text { Follicle } \\
\text { Stimulating Hormone }(\mathrm{mlu} / \mathrm{L})\end{array}$ & $\begin{array}{l}\text { Testosterone } \\
(\mathrm{ng} / \mathrm{ml})\end{array}$ \\
\hline Control & $3.1 \pm 0.22$ & $1.6 \pm 1.50$ & $2.3 \pm .06$ \\
P.a. 50 & $3.1 \pm 0.28$ & $1.5 \pm 0.17$ & $* 2.6 \pm 0.42$ \\
P. .100 & $3.1 \pm 0.25$ & $1.4 \pm 0.01$ & $* 2.8 \pm 0.30$ \\
P.a.200 & $3.1 \pm 0.01$ & $1.5 \pm 0.04$ & $* * 3.4 \pm 0.45$ \\
P.a.400 & $3.0 \pm 0.15$ & $1.5 \pm 0.02$ & $* * 4.3 \pm 0.48$ \\
P.a 800 & $3.1 \pm 0.08$ & $1.5 \pm 0.13$ & $* * 3.9 \pm 0.56$ \\
Vit. E (500IU) & $2.7 \pm 0.01$ & $1.4 \pm 0.01$ & $* 3.0 \pm 0.01$ \\
\hline
\end{tabular}

Values are expressed as mean \pm SEM of five observations $(n=5)$.

$*$ represents significant values at $\mathrm{P}<0.05$ and ** significant values at $\mathrm{P}<0.001$ (ANOVA). P.a means Phyllanthus amarus.

Table 2: Phytochemiacal Screening

\begin{tabular}{ll}
\hline Phytochemicals & P.amarus \\
\hline Alkaloids & + \\
Flavonoids & + \\
Terpenoids & + \\
Saponins & + \\
Tannins & + \\
steroid & + \\
Resins & - \\
\hline Cardiac glycosides & + \\
\hline
\end{tabular}

$+=$ present

- = absent 
Table 3: The comparative effects of the time - dependent effects of methanolic extracts of the leaf of Phyllanthus amarus and Vitamin E, overtime on the hormonal parameters of the male guinea pigs.

\begin{tabular}{llll}
\hline $\begin{array}{l}\text { Treatment } \\
\text { Period } \\
(400 \mathrm{mg} / \mathrm{kg})\end{array}$ & $\begin{array}{l}\text { Leutenizing } \\
\text { Hormone } \\
(\mathrm{mlu} / \mathrm{L})\end{array}$ & $\begin{array}{l}\text { Follicle } \\
\text { Stimulating } \\
\text { Hormone }(\mathrm{mlu} / \mathrm{L})\end{array}$ & $\begin{array}{l}\text { Testosterone } \\
(\mathrm{ng} / \mathrm{ml})\end{array}$ \\
\hline Control & $3.1 \pm 0.22$ & $1.6 \pm 1.50$ & $2.3 \pm .06$ \\
Vit. E $(500 \mathrm{IU})$ & $2.7 \pm 0.01$ & $1.4 \pm 0.01$ & $* 3.0 \pm 0.01$ \\
P.a at 7 days & $3.0 \pm 0.15$ & $1.5 \pm 0.02$ & $* 3.4 \pm 0.50$ \\
Vit. E & $3.1 \pm 0.16$ & $1.5 \pm 0.14$ & $* 2.9 \pm 0.16$ \\
P.a. at 14 days & $3.1 \pm 0.11$ & $1.4 \pm 0.04$ & \\
& & & $2.1 \pm 0.30$ \\
Vit.E & $3.1 \pm 0.13$ & $1.5 \pm 0.05$ & $2.4 \pm 0.45$ \\
P.a. at 21 days & $3.2 \pm 0.05$ & $1.4 \pm 0.01$ & \\
& & & $2.6 \pm 0.01$ \\
Vit. E & $2.5 \pm 0.01$ & $1.4 \pm 0.02$ & $2.4 \pm 0.50$ \\
P.a. at 28 days & $3.0 \pm 0.03$ & $1.4 \pm 0.03$ & \\
\hline
\end{tabular}

Values are expressed as mean \pm SEM of five observations $(n=5)$.

* represents significant values at $\mathrm{P}<0.05$ and ** significant values at $\mathrm{P}<0.001$ (ANOVA). P.a means Phyllanthus amarus.

This study shows the effects of methanolic extract of the leaves of phyllanthus amarus on the hormonal parameters of male guinea pigs. The results show that Phyllanthus amarus leaf extract causes an increases in the level of testosterone but has little or no effect on the levels of Leutinizing hormone (LH) and follicle stimulating hormone (FSH), (table 1 and 3; fig 1).The increase in the level of testosterone was found to be statistically significant at $\mathrm{P}<0.001$ (ANOVA). The increase in the testosterone may be responsible for the effect of the aerial part of this plant as a libido enhancer of fertility agent as claimed by traditional medicine practitioners. This is so because optimum level of testosterone is required for normal sex drive in adult male and an increase in the level of testosterone can lead to an increase in the spermatozoa (Vander et al., 2001) and hence an increase in male fertility (Vander et al., 2001).

The phytochemicals found present in the leaf of $P$. amarus include: flavonoids, tannins, saponins, alkaloids, terpenoids, steroids and cardiac glycosides. Flavonoids present in this plant has been shown to possess many pharmacological properties such as: anti-oxidant activities, anti-inflammatory activities, anti- cancer activities and anti- microbial effects hence, flavonoids may have a contributory effect to its fertility properties and other pharmacological effects the plant possesses( Joy and Kuttan, 1998; Kassuya et al., 2003; Adeneye, 2006).Favonoids as an anti-oxidant, has a rejuvenating effects on cells or tissues, it is anti-aging hence can contribute substantially on the fertility effect of this plant. Alkaloids and tannins may also contribute to the plant's effects as antimalarial, anti- diarrhea and analgesic agents.

This study therefore, supports the claims on the folkloric use of the aerial part of this plant to improve libido and reproductive function in men. However, further study needs to be to investigate the actual contribution of the seed of this plant as a fertility agent and also to isolate, identify and characterize the active principle present in the leaf of this plant.

\section{REFERENCE}

Adeneye, A.A; Benebo, A.S; Agbaje, E.O (2006). Protective effect of the Aqueous Leaf and seed Extract of Phyllanthus amarus on Alcohol induced hepatotoxity in rats. West Afr. J. Pharmacol. Drug Res. 22\&23 :42-50

Adeneye A. A; Amole, O.O; Adeneye, A. K (2006). The hypoglycemic and hypocholesterolemic activities of the aqueous leaf and seed extracts of Phyllanthus amarus in mice. Fitoterapia. 77: 511-514.

Iwu, M.M (1993). Modalities of drug administration. In : Hand book of African Medicinal Plants. CRC Press Inc. Florida. 309- 330.

Joy, K.L; Kuttan, R (1998) Inhibition by Phyllanthus amarus of hepatocarcinogenesis induced by $\mathrm{N}-$ Nitrosodiethylamine. J. Bioch. Nutr. 24: 133139.

Kassuya, C.A; Silerstre, A.A; Rehder, V; Calixto J.B (2003). Anti allodynic and antioedematogeni properties of the lignan from Phyllanthus amarus in models of persistent inflammatory and neuropathic pain Eur. J Pharm . 478: 145-153.

Kokwaro, J.O (1976). Medicinal Plants of East Africa Literature Bureau. 95

Meixa, W; Haowei, C ; Yanji, L (1995). Herbs of the genus phyllanthus amarus in the treatment of chronic hepatitis B: Observation with three preparations from different geographical sites. J. Lab. Clin. Med.126:350-352 
Odebedy O and Sofowora (1978). Phytochemical screening of Nigerian medicinal plants Lloydia 41: 41-234.

Odetola, A.A; Akkojenu S.M (2000). Antidiarrhoeal and gastrointestinal potentials of the aqueous extracts of Phyllanthus amarus (Euphorbiaceae). Afri. J.Med. Sci.29: 119-122.

Sofowora, A (1993). Medicinal Plants and Traditional Medicine in Africa. Spetrum books.
Thyagarajan S.P; Subramanian, S; Thirunalasundar, T (1988). Effects of Phyllanthus amarus on the chronic carriers of hepatitis B virus. Lancet 2: 764-766.

Trease, G.E; Evans W.C (1989). Trease and Evans Pharmacognosy. A physician guide to Herbal medicine $13^{\text {th }}$ edition: Ballere tindal London

Vander, A; Sherman, J; Luciano, D (2001). Human Physiology: The Mechanism of body function: McGraw- Hill higher Education. New York U.S.A $8^{\text {th }}$ edn. Pp 641-647. 